\title{
Comparative aspects of prepartum maturation: Provision of nutrients
}

\author{
Abigail L. Fowden, Jennifer C. Ousey and Alison J. Forhead \\ Department of Physiology, University of Cambridge, Cambridge, CB2 3EG, UK.
}

\begin{abstract}
Summary
At birth, the pattern of nutrition changes from a continuous but limited supply of nutrients from the placenta to an intermittent yet more plentiful provision of metabolic substrates via the gut. The success of this transition from parenteral to enteral nutrition depends on adequate fuel reserves, functional mechanisms for regulating nutrient utilization and production, a gastrointestinal tract competent at digestion and sufficient motor development to allow suckling. Maturational changes in key tissues (eg liver, gut) and endocrine systems (eg pancreas, adrenal) therefore occur during late gestation in preparation for the nutritional transition at birth. In many species, these maturational changes are dependent on the prepartum increase in cortisol secretion by the fetal adrenal. In fetal sheep, cortisol has been shown to stimulate hepatic glycogen deposition, induce hepatic gluconeogenic enzymes and adrenoreceptors and accelerate the structural and functional development of the gut. In fetal horses, prepartum maturation of the glucogenic and glucoregulatory capacities occurs comparatively late in gestation coincidentally with the natural rise in fetal plasma cortisol which occurs much closer to term in this than other domestic species. The relatively narrow window for glucocorticoid dependent maturation in the foal has consequences for survival both in utero in response to adverse conditions and at birth. Fetal foals are unable to produce glucose endogenously during late gestation and develop severe hypoglycaemia if delivered prematurely. Foals born with low cortisol levels therefore adapt poorly to extrauterine life while, conversely, increasing fetal glucocorticoid levels by betamethasone administration or by stress induced fetal cortisol secretion can lead to early delivery of viable foals which are normoglycaemic and able to digest enteral feeds. Increase prenatal exposure to glucocorticoid therefore appears to be as much a prerequisite for the neonatal transition from parenteral to enteral nutrition in the horse as it is in other species.
\end{abstract}

Keywords: $\quad$ maturation, nutrition, fetus, neonate

\section{Vergleichende Aspekte präpartaler Reifungsvorgänge: Bereitstellung von Nährstoffen}

Mit der Geburt ändern sich die Ernährungsbedingungen von der kontinuierlichen aber limitierten Versorgung über die Plazenta zu einem intermittierenden aber reichlichen Angebot metabolischer Substrate über den Verdauungskanal. Der Erfolg des Überganges von parenteraler zur enteralen Ernährung ist abhängig von adäquaten Nährstoffreserven, funktionierenden Regulationsmechanismen für die Nährstoffverwertung und -produktion, einem für die Verdauung kompetenten Gastrointestinaltrakt sowie einer ausreichenden Entwicklung des Neugeborenen, die den Saugakt erlaubt. Reifungsvorgänge in den Schlüsselgeweben (z.B. Leber, Darm) und im endokrinen System (Pankreas, Nebenniere) setzen daher in der letzten Trächtigkeitsperiode ein, um den Ernährungswechsel zur Geburt vorzubereiten. Bei vielen Tierarten sind diese Veränderungen von der fetalen, pränatal ansteigenden, adrenergen Kortisolsekretion abhängig. Es konnte gezeigt werden, dass bei Schaffeten Kortisol die Speicherung von Glykogen in der Leber stimuliert, glukoneogene Leberenzyme und Adrenorezeptoren induziert sowie die strukturelle und funktionelle Entwicklung des Darmes beschleunigt. Bei equinen Feten beginnt die pränatale Entwicklung der glukogenen und glukoregulativen Kapazitäten relativ spät in der Trächtigkeit, jedoch zeitgleich mit dem natürlichen Anstieg fetaler Plasmakortisole, der beim Pferd ebenfalls näher zum Geburtstermin einsetz† als bei anderen Haustieren. Das beim Fohlen relativ enge Zeitfenster für ein gluko-kortikoidabhängige Reifung hat Konsequenzen für ein Überleben sowohl im Uterus im Falle ungünstiger Umstände als auch perinatal. Pferde-feten sind nicht in der Lage während der letzten Gestationsphase endogen Glukose zu produzieren und entwickeln schwere Hypoglykämien bei vorzeitiger Geburt. Daher ist die Adapatationsfähigkeit an das extrauterine Leben bei Fohlen, die geringe Kortisolwerte aufweisen, schlecht. Umgekehrt können durch Betamethasonapplikationen oder eine durch Stress induzierte erhöhte fetale Kortisolsekretion zu einer vorzeitigen Geburt lebensfähiger Fohlen führen, die eine Normoglykämie aufweisen und die in der Lage zur enteralen Vedauung sind.

Der pränatale Anstieg von Glukokortikoiden scheint beim Fohlen eine im Vergleich zu anderen Spezies außerordentlich wichtige Bedingung für den Übergang des Neonaten von der parenteralen zur enteralen Entwicklung der Ernährung zu sein.

Schlüsselwörter: Reifung, Ernährung, Fetus, Neugeborener

\section{Introduction}

In adults, nutrients are provided by several different tissues, whereas in the fetus, they are supplied primarily by the placenta. There are also changes in the quantity, type and temporal pattern of the nutrient supply at birth. Before birth, the nutrient supply is continuous but finite while after birth, it is intermittent yet more plentiful. A successful transition from intra- to extrauterine life therefore depends on the ability of specific tissues and organ systems to take over the functions of the placenta at birth and to regulate circulating nutrient concentrations for the first time. The aims of this comparative review are therefore three fold: first, to discuss the prepartum maturational changes essential for nutritional adaptation at birth; secondly, to examine the glucocorticoid dependence of these maturational changes and, thirdly, to consider the consequences of the temporal sequence of prepartum maturation on neonatal viability in different species. 


\section{Prepartum preparation for nutritional adaptation at birth}

The transition from parenteral to enteral nutrition at birth is multifactorial and involves coordinated interactions between many different organ systems. In particular, it requires adequate fuel reserves, functional mechanisms for regulating nutrient utilization and production, a gastrointestinal (GI) tract competent at digestion and sufficient motor development to allow sucking and motility in precocial species like the horse (Fig. 1). Organs such as the liver, kidney, pancreas and gut therefore undergo maturational changes during late gestation in preparation for the nutritional transition at birth (Fowden et al., 1998).

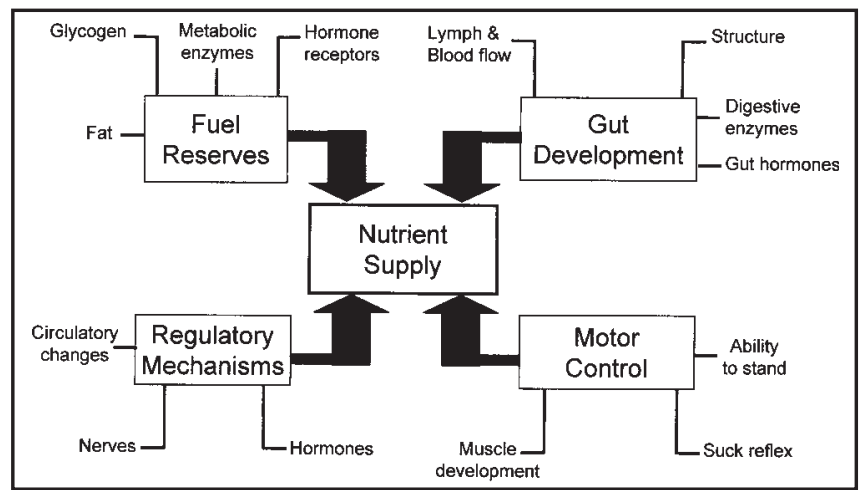

Fig. 1: Schematic diagram of the factors affecting the supply of nutrients in newborn animals.

Schematisches Diagramm der Faktoren, die die Versorgung neugeborener Tiere mit Nährstoffen beeinflussen.

\section{Fuel Reserves}

Survival during the period between placental separation and the establishment of nutritive suckling depends on the fuel reserves. These are laid down in the fetus towards term in the form of glycogen and fat. The fat content of the domestic species rises progressively during the last $10 \%$ of gestation and ranges from 1-3\% at birth (Fowden, 1997; Ousey, 1997). Fat is not utilized in utero but can be mobilized readily after birth to provide free fatty acids for oxidative metabolism. Studies in the lamb suggest that neonatal fat mobilization depends on withdrawal of a placental product that normally inhibits lipolysis in utero (Harding and Johnston, 1995). The fat reserves account for $70-80 \%$ of the stored energy in neonatal sheep but only $50-60 \%$ of the total energy available to newborn pigs and horses. Hence, survival immediately after birth also depends on the glycogen stores, particularly in pigs and horses.

In all species studied so far, there is an increase in hepatic glycogen deposition towards term (Shelley, 1961). In most species, the hepatic glycogen content increases 5-10 fold during the last $30 \%$ of gestation but, in fetal horses, the increment is less and occurs closer to term in the final 5\% of gestation (Fig. 2a). Prepartum increases in glycogen content also occurs in other fetal tissues, such as kidney, heart and skeletal muscle, with species specific time courses similar to those seen in the fetal liver (Fowden et al., 1991). Mobilization of glycogen to produce circulating glucose requires the enzyme, glucose-6phosphatase (G-6-Pase). This enzyme is found in fetal liver and kidney but not in lung, heart or skeletal muscle (Fowden et al., 1993). Glycogen stored in the lung, heart and skeletal muscle therefore provides glucose carbon for use within the tissue while that stored in the liver and kidney can contribute to the circulating glucose pool. Tissue G-6-Pase activities increase towards term in parallel with glycogen deposition in the fetal liver and kidney and, hence, rise much closer to term in fetal horses than in other domestic species (Fig. 2b).

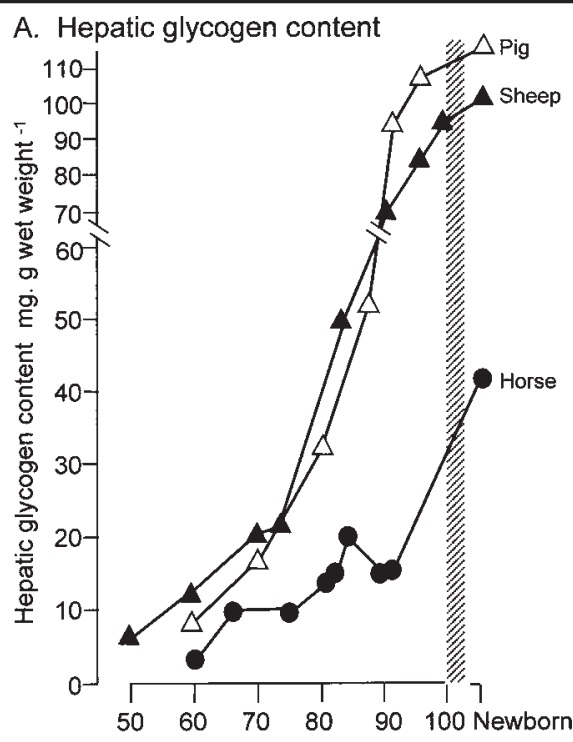

B. Hepatic glucose-6-phosphatase

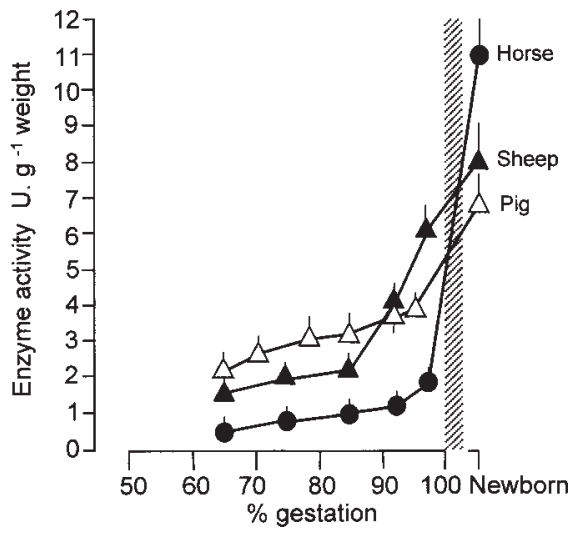

Fig. 2: Mean ( \pm SE) values of a) glycogen content and b) glucose-6phosphatase activity in liver from fetal and newborn pigs (+), sheep $(\%)$ and horses (\#) with respect to the stage of gestation. Data from Fowden et al. 1991

Mittelwerte ( \pm Standardabweichung) von a) Glycogenmenge und b) Glucose-6-Phosphatase-Aktivität in der Leber von fetalen und neugeborenen Schweinen (+), Schafen (\%) und Pferden (\#) in Abhängigkeit von dem Trächtigkeitsstadium. Daten von Fowden et al. 1991.

Glycogen stores in the liver and skeletal muscle are depleted within 24h of birth (Shelley, 1961). Thereafter, the neonate is dependent on its gluconeogenic capacity to meet the deficit between the glucose supply and demand. Glucose can be produced de novo in the liver and kidneys from lactate and amino acids using specific gluconeogenic enzymes. These enzymes have been detected in the fetal liver and kidney during late gestation in the horse and other domestic species (Fowden et al., 1993). The absolute activities of these enzymes vary 
amongst species but invariably increase towards term although with different time courses in different animals (Fowden et al., 1993). Like G-6-Pase, the prepartum rise in specific gluconeogenic enzyme activities occurs comparatively late in gestation in fetal equine liver.

\section{Gut development}

In fetal pigs and sheep, there are structural and functional changes in the gut during late gestation which are essential for enteral nutrition after birth (Sangild and Trahair, 1997). There are increases in the depth and height of the villi in the gut mucosa and in the amount of smooth muscle present in the gut wall. In addition, there are increases in the activity of the major digestive enzymes in the stomach, pancreas and small intestine of fetal sheep and pigs during the last 10-15\% of gestation (Sangild and Trahair, 1997). Blood flow to the gut and Gl motility rise close to term and increase still further once suckling begins (Sangild et al., 2000). There are also prepartum maturational changes in the endocrine mechanisms regulating gut function. For example, gastrin concentrations and the sensitivity of gastrin release both rise towards term in fetal sheep and pigs (Sangild et al., 2000).

Structural and functional maturation appears to proceed in a proximal to distal direction along the GI tract. Developmental changes begin in the stomach before birth and are not complete in the proximal small intestine and colon until after birth in sheep and pigs (Sangild and Trahair, 1997). Hence, the organs first receiving the milk are matured before the lower portions of the $\mathrm{Gl}$ tract. The final developmental changes in the distal small intestine and colon probably depend on luminal exposure to growth factors in the milk or on the systemic effects of gastrointestinal peptides released in response to suckling.

Compared with the sheep and pig, relatively little is known about the prepartum development of the equine $\mathrm{Gl}$ tract. Absorption of immunoglobulins occurs rapidly in newborn foals which indicates that the proximal $\mathrm{Gl}$ tract is sufficiently mature at birth to absorb these large macromolecules (Jeffcott, 1972). The concentrations of various gastrointestinal peptides, such as gastrin and enteroglucagon, also rise in response to suckling in newborn foals (Ousey et al., 1995). However, the extent to which the structural and functional changes in the fetal equine gut resemble those seen in other species before birth remains unknown.

\section{Regulatory Mechanisms}

Before birth, fetal glucose concentrations are determined primarily by maternal glucose availability and, hence, by maternal homeostatic mechanisms. Consequently, endocrine glands, such as the pancreas and adrenal, are not directly glucoregulatory in utero although they can respond to changes in fetal glycaemia (Fowden, 1995). However, after birth, the neonate must be able to regulate its glucose level in the face of an intermittent nutrient supply. This requires functional mechanisms to sense the degree of glycaemia and to effect changes in glu- cose metabolism. There are, therefore, maturational changes in many of the endocrine and neural mechanisms involved in glucose homeostasis during the perinatal period (Fowden, 1995).

Towards term, the endocrine pancreas becomes increasingly responsive to metabolic stimuli. In both sheep and horses, the pancreatic $\beta$ cell response to exogenous glucose increases in magnitude and duration with proximity to delivery and again after birth (Fowden et al., 1984; Aldoretta et al., 1998). There is also a progressive shift in the slope of the relationship between the endogenous concentrations of glucose and insulin during the perinatal period (Fowden et al., 1982). Both the set point and sensitivity of glucose-stimulated insulin secretion are therefore altered at birth (Fowden et al., 1984). Similarly, the pancreatic $\alpha$ cell response to arginine increases in magnitude during late gestation in fetal sheep and horses (Aldoretta et al., 1998; Fowden et al., 1999). Basal circulating glucagon concentrations also rise during late gestation in fetal pigs, sheep and horses (Fowden et al., 1999; Fowden and Hill, 2001). In addition, innervation of the islets of Langerhans is completed during late gestation in most species (Fowden and Hill, 2001). These maturational changes therefore ensure that the endocrine pancreas assumes a full glucoregulatory role immediately after birth.

Similar prepartum maturational changes occur in the sensitivity of the fetal adrenal medulla and hypothalamic-pituitary-adrenal (HPA) axis to adverse stimuli in utero. In both fetal sheep and horses, there is increased secretion of catecholamines, ACTH and cortisol in response to insulin-induced hypoglycaemia as term approaches (Silver and Edwards, 1980; Silver et al., 1987). The innervation to the adrenal medulla also becomes progressively more effective at releasing catecholamines in response to stressful stimuli. For instance, during the last 20 days of gestation in fetal sheep, hypoxaemia-induced release of adrenal catecholamines switches from a direct medullary response to low $\mathrm{pO}_{2}$ to a indirect neural response mediated via the splanchnic nerves (Silver and Edwards, 1980). Furthermore, the activity of adrenal phenyl-N-methyl transferase (PNMT) increases towards term and, hence, circulating adrenaline concentrations rise in late gestation. In the foal, activation of adrenomedullary adrenaline secretion occurs very close to term with little, if any, adrenaline secretion in response to hypoglycaemia before birth but a rapid adrenaline increment in hypoglycaemic neonates (Silver et al., 1987; Silver and Fowden, 1995). Certainly, at birth, the increment in plasma catecholamine concentrations in the foal is similar in magnitude to that seen in other domestic species (Table 1).

By term, all the endocrine glands involved in glucose homeostasis are sufficiently mature to respond to the stress of labor and delivery. Receptors for the glucoregulatory hormones are also present in a range of fetal tissues by late gestation (Fowden et al., 1998). At birth, there are increases in the hyperglycaemic hormone levels and a fall in the plasma insulin level (Table 1). These endocrine changes mobilize the fuel reserves by activating glycogenolysis, gluconeogenesis and lipolysis. They also limit utilization of circulating glucose by insulin-sensitive peripheral tissues, such as skeletal muscle. Consequently, the glucose supply to essential tissues, such as the brain, is maintained during and immediately after delivery. 


\section{Motor Control}

In precocial species like the horse, motor control is well developed at birth compared with altricial species. Newborn foals can stand and suck within 30-60 minutes of birth and run shortly thereafter (Rossdale et al., 1984). Some of the reflexes and physical characteristics central to these processes develop relatively late in gestation. Hence, foals delivered prematurely often have dropped fetlocks and poor righting reflexes. This impairs their ability to stand and suck and has adverse consequences for enteral nutrition and immunoglobulin acquisition (Rossdale et al., 1984). In contrast, the suck and oesophageal reflexes develop relatively early in the sequence of CNS maturation in domestic species. Provided the GI tract is sufficiently mature, feeding colostrum and milk by bottle or stomach tube may be an effective means of providing nutrition until the neonate can stand unaided (Ousey et al., 1991; Ousey, 1997).

\section{Glucocorticoid dependence of prepartum maturation}

In all species studied so far, there is an increase in fetal plasma cortisol concentrations towards term (Fig. 3). In fetal sheep, the rise in plasma cortisol occurs over the last 10-15 days and is responsible for increasing the fetal glucogenic capacity (Fowden et al., 1998). Cortisol increases glycogen deposition and gluconeogenic enzyme activities in fetal ovine and porcine liver (Fowden et al., 1998). It also activates adrenomedullary PNMT activity and induces expression of receptors for adrenaline and other hormones involved in regulating the nutrient supply postnatally (Fowden et al., 1998). Many of the prepartum maturational changes that occur in the fetal gut are also cortisol dependent in sheep and pigs (Sangild et al., 2000). Cortisol is therefore essential for a successful nutritional transition at birth in these species.

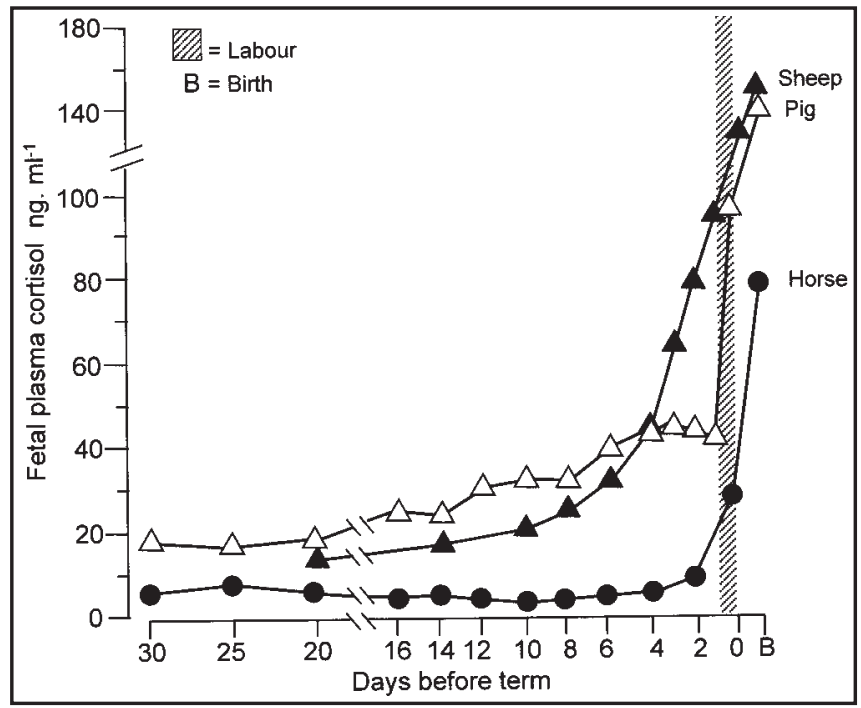

Fig. 3: Mean concentrations of plasma cortisol in fetal pigs (+), sheep $(\%)$ and horses (\#) with respect to days from delivery. Data from Fowden et al. 1998.

Mittlere Konzentration des Plasmakortisols bei fetalen Schweinen (+), Schafen (\%) and Pferden (\#) in Abhängigkeit von der Anzahl Tage vor der Geburt. Daten von Fowden et al. 1998.
Less is known about the effects of cortisol on maturation of these systems in fetal horses. There have been no studies specifically manipulating fetal cortisol concentrations in this species. Fetal administration of ACTH or the synthetic glucocorticoid, betamethasone, has been shown to lead to early delivery of viable foals which are capable of standing, sucking and digesting enteral feeds. (Rossdale et al., 1992; Ousey et al., 1998). Similarly, maternal administration of ACTH appears to accelerate maturation of the fetal foal (Ousey et al., 2000). Prepartum maturation of the glucogenic capacity and other systems in the fetal horse also occurs comparatively late in gestation coincidently with the natural rise in fetal plasma cortisol in the last 24-48h before birth (Fig. 3). Taken together, these observations indicate that increased prenatal exposure to glucocorticoids is as much a prerequisite for the neonatal transition from parenteral to enteral nutrition in the horse as it is in other species.

\section{Consequences of the prepartum maturational sequence}

The relatively late increase in glucogenic capacity in fetal horses has consequences for survival both in utero during adverse conditions and at birth. Compared with fetal sheep, fetal horses have a reduced capacity to maintain their circulating glucose levels during short term maternal fasting (Fig. 4). Measurements of glucose metabolism show that glucogenesis is negligible in fetal horses during both adverse and normal conditions near term (Fowden, 1997; Fig. 5). This inability to produce glucose endogenously may explain, in part, the increased vulnerability of the fetal horse to undernutrition during late

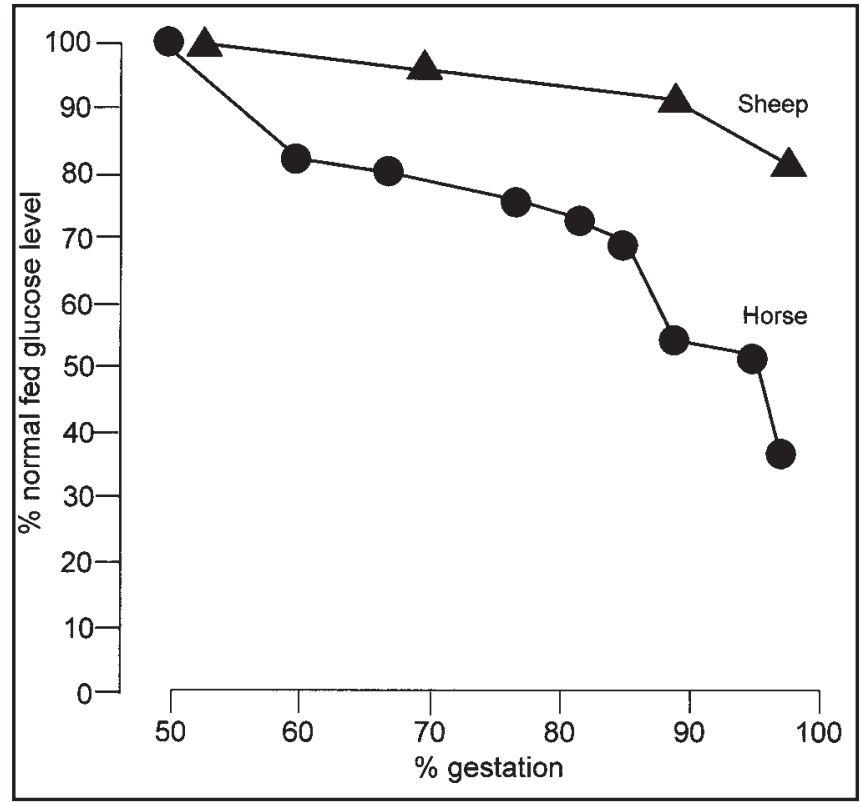

Fig. 4: Mean percentage changes in fetal plasma glucose concentration in response to a $24 \mathrm{~h}$ period of maternal food withdrawal with respect to the stage of gestation in sheep (\%) and horses (\#). Data from Fowden et al. 1994

Mittlere prozentuale Veränderungen in der fetalen Plasmaglukosekonzentration als Antwort auf einen 24-stündigen maternalen Futterentzug in Abhängigkeit von dem Trächtigkeitsstadium bei Schafen (\%) und Pferden (\#). Daten von Fowden et al. 1994. 
gestation (Fowden et al., 1994). Certainly, profound hypoglycaemia is a common clinical feature of equine prematurity (Rossdale et al., 1984). However, by full term, the glucogenic capacity of the foal has improved sufficiently for glucose levels to be maintained for at least $2 \mathrm{~h}$ after birth without sucking (Fowden et al., 1984).

In fetal sheep and pigs, the glucogenic capacity rises earlier in gestation in parallel with the earlier onset of increased adrenocortical activity (Figs. 2 and 3). Fetal sheep and pigs can therefore produce glucose endogenously in response to undernutrition and other adverse intrauterine conditions (Fowden, 1997). However, the fetal pig, like the fetal horse, does not activate glucogenesis in normal nutritional conditions, even close to term (Fig. 5). Since the glucogenic capacity of the fetal pig is high at

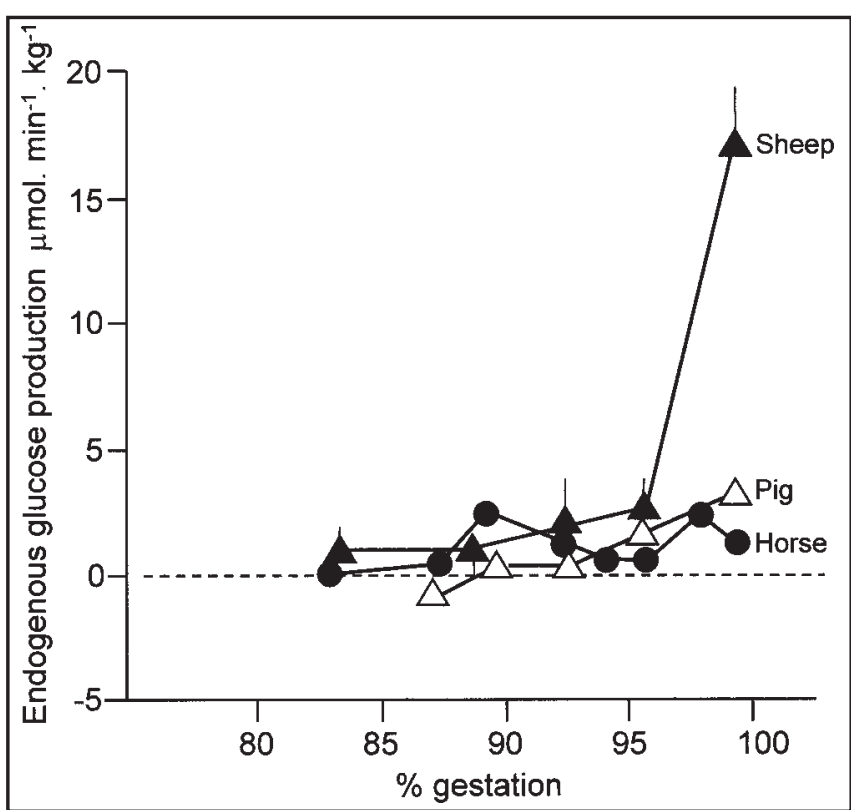

Fig. 5: Mean $( \pm$ SEM) rates of endogenous glucose production in fetal pigs (+), sheep (\%) and horses (\#) in well-fed conditions with respect to the stage of gestation. Data from Fowden, 1997.

Mittlere Rate $( \pm$ SEM) der endogenen Glucoseproduktion bei fetalen Schweinen (+), Schafen (\%) und Pferden (\#) unter guten Fütterungsbedingungen in Abhängigkeit vom Trächtigkeitsstadium. Daten von Fowden, 1997.

this time (Fig 2), the lack of prepartum glucogenesis in pigs may reflect species differences in the fetal endocrine environment (Table 1). Hence, fetal pigs and horses, unlike fetal sheep, conserve their glucose reserves until after birth. This ensures that the maximum amount of glycogen is available for the neonatal transition in nutrition and is consistent with the low stores of glycogen and fat found in newborn horses and pigs respectively (Fowden, 1997).

\section{Conclusions}

The relatively late and rapid increase in adrenocortical activity just before term in the fetal horse means that there is only a very narrow window for glucocorticoid dependent maturation in this species (Fowden and Silver, 1995a). This poses a major threat to survival of the foal if delivery occurs much before full term and leads to a higher incidence of equine prematurity than seen in other domestic species (Rossdale et al., 1984). Certainly, foals born with low cortisol levels adapt poorly to extrauterine life and have little chance of long term survival, even when delivered within the normal range of gestational lengths (Rossdale et al., 1984). However, the speed with which the final prepartum maturation occurs in the foal suggests that equine tissues near term may respond readily to a comparatively short exposure to cortisol. Hence, glucocorticoid administration to prematurely delivered foals or to mares threatening preterm delivery may provide an effective clinical treatment for improving the poor viability of these foals. Certainly, conditions, such as placentitis and placental separation, which cause intrauterine stress and which probably raise cortisol levels in utero, induce precocious maturation and lead to the delivery of viable foals at gestational ages normally incompatible with neonatal survival.

\section{Acknowledgements}

We would like to thank Paul Hughes for his help with the surgery, Sue Nicholls and Vicky Johnson for the care of the animals, Malcolm Bloomfield for his assistance with the biochemical analyses and Nicola Allanson for typing the manuscript. We are indebted to the Biotechnology and Biological Sciences Research Council, the Horserace Betting Levy Board and the Wellcome Trust for their financial support of this work.

\section{Literature}

Aldoretta, P.W., Carver, T.D. and Hay, W.W. (1998): Maturation of glucose-stimulated insulin secretion in fetal sheep. Biol. Neonate. 73, 375-386.

Tab. 1: Arteriell plasma concentrations of cortisol, adrenaline, noradrenaline, insulin and glucagon in fetuses of different species at $95 \%$ of gestation ans at birth. Data from Fowden et al. 1984, 19956, 1999; Silver et al. 1986, 1987

Arterielle Plasmakonzentration von Kortison, Adrenalin, Noradrenalin, Insulin und Glucagon in Feten verschiedener Tierarten nach 95\% der Trächtigkeit und zum Zeitpunkt der Geburt. Daten von Fowden et al. 1984, 1995b, 1999; Silver et al. 1986, 1987

\begin{tabular}{|c|c|c|c|c|c|c|c|c|c|c|}
\hline & \multicolumn{2}{|c|}{ Cortisol ng. $\mathrm{ml}^{-1}$} & \multicolumn{2}{|c|}{ Adrenaline $\mathrm{ng} \cdot \mathrm{ml}^{-1}$} & \multicolumn{2}{|c|}{ Noradrenaline $\mathrm{ng} \cdot \mathrm{ml}^{-1}$} & \multicolumn{2}{|c|}{ Insulin $\boldsymbol{\mu} \cup \cdot \mathrm{ml}^{-1}$} & \multicolumn{2}{|c|}{ Glucagon pg.ml ${ }^{-1}$} \\
\hline & $95 \%$ & Birth & $95 \%$ & Birth & $95 \%$ & Birth & $95 \%$ & Birth & $95 \%$ & Birth \\
\hline Sheep & $55-65$ & $120-150$ & $0.65-0.75$ & $1.00-2.00$ & $0.25-0.35$ & $1.00-1.50$ & $20-25$ & $10-15$ & $200-400$ & $400-500$ \\
\hline Pig & $25-30$ & $140-150$ & $0.50-0.75$ & $1.75-2.25$ & $0.90-1.00$ & $3.00-3.50$ & $8-10$ & $5-10$ & $35-45$ & $200-300$ \\
\hline Horse & $15-20$ & 80-90 & $0.1-0.15$ & $2.00-3.00$ & $0.40-0.50$ & $3.50-4.50$ & $10-15$ & $5-15$ & $800-900$ & $1500-1800$ \\
\hline
\end{tabular}


Fowden, A.L. (1995): Endocrine regulation and fetal growth. Reprod. Fert. Develop. 7, 351-362.

Fowden, A.L. (1997): Comparative aspects of fetal carbohydrate metabolism. Equine Vet. J. Suppl. 24, 19-25.

Fowden, A.L., Forhead, A.J., Bloomfield, M., Taylor, P.M. and Silver, M. (1999): Pancreatic $\alpha$ cell function in the fetal foal during late gestation. Exp. Physiol. 84, 697-705.

Fowden, A.L. and Hill, D.J. (2001): Intrauterine programming of the endocrine pancreas. BMB (in press).

Fowden, A.L., Li, J. and Forhead, A.J. (1998): Glucocorticoids and the preparation for life after birth: are there long-term consequences of the life insurance? Proc. Nut. Soc. 57, 113-122.

Fowden, A.L., Mundy, L., Ousey, J.C., McGladdery, A. and Silver, M. (1993): The development of gluconeogenic enzymes in the liver and kidneys of fetal and newborn foals. J. Reprod. Fert. Suppl. 44, 537542.

Fowden, A.L., Ralph, M.M. and Silver, M. (1994): Nutritional regulation of uteroplacental prostaglandin production and metabolism in pregnant ewes and mares during late gestation. Exp. Clin. Endo. $102,212-221$.

Fowden, A.L. and Silver, M. (1995): Comparative development of pituitary-adrenal axis in the fetal foal and lamb. Reprod. Dom. Anim. 30, 170-177.

Fowden, A.I., Silver, M., Ellis, L., Ousey, J.C. and Rossdale, P.D. (1984): Insulin secretion in the foal during the perinatal period. Equine Vet J. 16, 286-291.

Harding, J.E. and Johnston, B.M. (1995): Nutrition and fetal growth. Reprod. Fertil. Dev. 7, 539-547.

Jeffcott, L.B. (1972): Passive immunity and its transfer with special reference to the horse. Biol. Rev. 47, 439-464.

Ousey, J.C. (1997): Thermoregulation and the energy requirement of the newborn foal, with reference to prematurity. Equine vet J. Suppl. 24, 104-108.

Ousey, J.C., Ghatei, M., Rossdale, P.D. and Bloom, S.R. (1995): Gut hormone response to feeding in healthy pony foals aged $0-7$ days. Biology of Reproduction Monographs 1, 87-96.

Ousey, J.C., Rossdale, P.D., Dudan, F.E. and Fowden, A.L. (1998): The effects of intra-fetal ACTH administration on the outcome of pregnancy in the mare. Reprod. Fert. Dev. 10, 359-367.

Ousey, J.C., Rossdale, P.D., Palmer, L., Grainger, L. and Houghton, E. (2000): Effects of maternally administered Depot $\mathrm{ACTH}_{1-24}$ on fetal maturation and the timing of parturition in the mare. Equine Vet. J. 32, 489-496.

Rossdale, P.D., McGladdery, A.J., Ousey, J.C., Holdstock, N.B., Grainger, L. and Houghton, E. (1992): Increase in plasma progestogen concentrations in the mare after foetal injection with $\mathrm{CRH}, \mathrm{ACTH}$ or betamethasone. Equine Vet. J. 24, 347-350.

Rossdale, P.D., Ousey, J.C., Silver, M. and Fowden, A.L. (1984): Studies on equine prematurity VI: Guidelines for assessment of foal maturity. Equine Vet. J. 16, 300-302.

Sangild, P. and Trahair, J. (1997): Systemic and luminal influences on the perinatal development of the gut. Equine Vet. J. 24, 4-50.

Sangild, P., Fowden, A.L. and Trahair, J. (2000): How does the fetal gastrointestinal tract develop in preparation for enteral nutrition after birth? Livestock Production Sciences 66, 141-150.

Shelley, H.J. (1961): Glycogen reserves and their changes at birth and in anoxia. Br. Med. Bull.17, 137-143.

Silver, M. and Edwards, A.V. (1980): The development of the sympatho-adrenal system with an assessment of the role of the adrenal medulla in the fetus and neonate. In Biogenic Amines in Development. Ed H Parvez and S Parvez, Elsevier, 147-212.

Silver, M. and Fowden, A.L. (1995): Sympathoadrenal and other endocrine and metabolic responses to hypoglycaemia in the fetal foal during late gestation. Exp. Physiol. 80, 651-662.

Silver, M., Fowden, A.L., Ousey, J.C., Knox, J. Franco R. and Rossdale, P.D. (1987): Sympathoadrenal response to hypoglycaemia in the foal. J. Reprod. Fert. Suppl. 35, 607-614.

A. L. Fowden

Department of Physiology

University of Cambridge

Downing Street

Cambridge

CB2 3EG

UK

Tel: 01223333855

Fax: 01223333840

E-mail:alf1000@cam.ac.uk 